\title{
The Empirical Analysis of Corporate Governance Mechanism and Political Influence on FRQ: An Insight from the Banking Sector in Iraq
}

\author{
Barzo Mahmoud Qader* Wan Sallha Yusoff \\ Centre of Excellent Social Innovation and Sustainability, \\ Faculty of Applied and Human Sciences, Universiti Malaysia Perlis.
}

\begin{abstract}
The global corporate scandals in the banking industry have gained the government's attention and other regulatory agencies on the importance of corporate governance, inducing legislation to prevent similar occurrences. Iraq has an emerging economy and corporate governance practices to establish and maintain a quality corporate culture. The study examined corporate governance and political influence on the financial reporting quality (FRQ) of 34 Iraqi banks listed under the 2015 - 2019 stock exchange. Specifically, the study provided a critical literature review on past studies to identify the strength and weaknesses and the literature gap. The study also used secondary data from financial reports. A total sample of 170 observation data was obtained as the analysis unit, selected through market capitalisation. Additionally, multiple linear regression was used to analyse the data using the Stata software. The results showed a positive and significant relationship between board size and FRQ. Conversely, board independence and audit committee independence had insignificant relationships with FRQ. Based on the ownership structure, managerial ownership significantly affected FRQ, whereas the political influence negatively impacted FRQ. Ultimately, the study contributes to the limited literature on the relationship between corporate governance and FRQ in Iraq's developing economy.
\end{abstract}

Keywords: Corporate Governance, Political Influence, Ownership Structure, FRQ, Iraq.

DOI: $10.7176 / \mathrm{RJFA} / 12-20-08$

Publication date:October $31^{\text {st }} 2021$

\section{Introduction}

A listed company's financial report is a crucial channel for existing and potential investors to make viable decisions. Hence, corporate governance could positively impact the FRQ. Recently, FRQ has gained increasing attention, being pervasive in all spheres of human activity (Huynh, 2020; Masud, Kaium, Bae, Manzanares, \& Kim, 2019). Besides, the wave of financial reporting scandals in the international community has raised criticisms on the FRQ. Global corporate failure and financial statement manipulation are recurring phenomena that failed to guarantee the credibility and transparency of financial statements (Huynh, 2020; Hermanto, 2019; Arieftiara \& Utama, 2018). Many studies have also highlighted the challenge of FRQ in financial institutions, particularly the banking industry. Despite various measures implemented by the regulatory agencies, poor FRQ still exist. Ismael and Mohammadi (2017) mentioned that FRQ depends on governance principles in developed and developing countries. Due to failure in financial disclosure, organisations have highlighted the need to improve FRQ and strengthen the control of managers by establishing strong governance structures.

The relationship between corporate governance and FRQ has been discussed extensively in developed countries, emphasising specific governance mechanisms: board structure (Klai \& Omri, 2011); auditors' effectiveness (Huynh, 2020; Rich, 2009; Agrawal \& Chadha, 2005); director shareholding (Sánchez - Ballesta \& García - Meca, 2007); ownership structure (Zulaikah, Larasati, \& Harymawan, 2019; Han, 2005). Nevertheless, developing stock markets are different from the developed stock market regarding the ownership structure, corporate governance code, and development stages (Arieftiara \& Utama, 2018). Thus, research focused on corporate governance and FRQ in emerging economies with distinctive characteristics about corporate regulations, control and capital allocation in the sector. Nonetheless, the area has not been comprehensively examined in Iraq.

The Iraqi constitution did not mention corporate governance, specifically investment law, capital market law, joint-stock companies law, and accounting and auditing standards (Doski, 2015; Najim, 2013). Al-Obeidi (2011) stated that corporate governance implementation is very low due to no issuing or establishing corporate governance codes and no relevant local laws determining corporate governance mechanisms. Additionally, limited evidence was found on the relationship between corporate governance and emerging economies such as Iraq. The study referred to Doski (2015), Khudair (2012), and Al-Obeidi (2011) on the importance of Iraqi corporate governance.

Iraq is an interesting case study on how corporate governance impacts FRQ due to many reasons based on the trending issues in Iraq, namely: improving the importance of corporate purposes; better board oversight of corporate culture and human capital management; a more expansive view of board diversity including ethnicity 
and race; companies facing a wider form of activism; and a greater focus on environmental, social and governance (ESG). Therefore, the study examines and identifies the link between corporate governance mechanisms and FRQ in board effectiveness, ownership structure, audit quality and political influence in Iraq financial sectors. Accordingly, the study objectives are as follows:

i. To examine the influence of board effectiveness and FRQ in Iraq banking institutions.

ii. To investigate the relationship between ownership structure and FRQ in Iraq banking institutions.

iii. To examine the impact of political influence on the FRQ in Iraq banking institutions.

\section{Literatures Review}

\subsection{FRQ}

The FRQ has gained considerable interest globally. Significantly, FRQ solves the increasing concern of existing and potential investors to increase public trust in business (Mbir, Agyemang, \& Tackie, 2020). Companies should improve the quality of reports for fast-tracking information, which impacts emerging risks of future business strategies. Hence, the risks organisations are exposed to, the actions that prevent uncertainties, the carrying value of assets and the recognition of liabilities due to reporting failure undermines trust in business (Hermanto, 2019; Arieftiara \& Utama, 2018). Consequently, management can miss the potential impact, nontransparent or not managing effectively.

The conceptual framework of 2010 financial reporting emphasised that financial reports present users with useful information in decision making to provide resources to the company (IASB, 2017). Trai Kha, Trung, and Dung (2018) categorised financial reporting as follows: financial statements, accompanying footnote disclosures, annual reports issued by shareholders, other financial information on the firms' website, and any prospectus to investors regarding the firm's issuance of securities. Past studies stated that financial reporting transparency is significantly and positively related to the proportion of outside directors on the board, the audit committee and the outside directors with financial expertise (Mohammed, Sanusi, Noordin, \& Harjito, 2016). Consequently, shareholders may appoint more outside directors when the information environment is friendly and transparent to improve the FRQ. Meanwhile, other studies have measured the FRQ using various methods. For instance, Beest, Braam, and Boelens (2009) explained the methods of measuring FRQ through the accrual method, value relevance method, and specific factors in the annual reports. Thus, the comprehensive measurement tools of FRQ encompass the complete annual financial and non-financial reports. The study also highlighted value relevance and accrual methods, mainly focusing on accounting financial figures to examine the FRQ. Therefore, this study focused on the annual report elements to determine the impact of adequate information in the annual report and users' accurate decision-making.

\subsection{Corporate Governance Mechanisms}

Corporate governance is a multifaceted subject to prevent entrepreneurs and owners from abusing on behalf of the organisation. According to Fekadu (2015), corporate governance ensures proper business governance and compliance with all governance norms by regulatory bodies to benefit all interested parties, including society (Almanasir \& Shivaraj 2017; Ene \& Bello, 2016). Paul, Ebelechukwu, and Yakubu (2015) mentioned that corporate governance involves ensuring accountability and transparency, building capability, and ensuring an effective channel of information disclosure that foster better corporate performance and enhance the FRQ.

Companies require corporate governance, which needs a good system to help build shareholder confidence and ensure all stakeholders are treated equally and appropriately. Besides, Mahrani and Soewarno (2018) expressed that a governance system provides shareholders effective protection to recover investments effectively and reasonably. Furthermore, Huyanh (2020) stated that corporate governance plays an essential role as improved practices are vital to attract investment opportunities and stimulate social welfare and economic growth and sustainability (Huynh, 2020; Hermanto, 2019; Antonio, Laela, \& Darmawan, 2019). The study added that effective governance is the communication channel between managers and shareholders that are well established and clear; risk management measures are in place and effectively formed strategic directions.

Terjesen, Couto and Francisco (2016) reviewed corporate governance on the role of financial reporting in resolving agency conflicts among company directors, managers and capital providers. Specifically, governance is a set of contracts that assists and aligns managers' and shareholders' interests and information asymmetry in the agency problems. The study revealed that financial reporting is valuable because contracts are more efficient when two parties commit themselves to a more transparent information environment. Mahrani and Soewarno (2018) suggested that financial reporting can reduce information asymmetries that impair the efficiency of essential governance mechanisms.

2.2.1 Board Effectiveness and Financial Reporting Quality

The study analysed the relationship between board effectiveness and FRQ. Past studies have reported the importance of board characteristics in ensuring a high level of FRQ. Hence, board characteristics such as board size, board diversity and board independence affect the FRQ level in organisations (Hermanto, 2019; Mahrani \& 
Soewarno, 2018; Kukah, Amidu, \& Abor, 2016; Fakhfakh, 2016; Doski, 2015; Chen, Cheng, \& Wang, 2015; Nelson \& Devi, 2013). Therefore, the study is divided into the following subsections:

2.2.2 Board Size and FRQ

Many studies have discussed the importance of board size with the firms' reporting quality. For example, Vafeas (2000) revealed that the larger the board size, the less effective the monitoring responsibility as it might spread among all directors. Different opinions might hinder larger boards from reaching decisions to produce a highquality financial statement. Due to the size of the BOD, less personal responsibility is levelled on each director. Additionally, Mbir et al. (2020) deduced that smaller board sizes tend to have a high level of FRQ. Beasley, Blay, Lewellen, and McAllister (2018) also established that the increase in board size could encourage more fraudulent financial activities. Therefore, the study proposed the following:

$H_{1} \quad$ There is a significant relationship between board size and FRQ in the Iraqi banking sector.

2.2.3 Board Gender Diversity and FRQ

From the agency theory perspective, female directors usually incorporate extensive ideas that increase board independence and improve the FRQ (Hillman \& Dalziel, 2003). Moreover, including female directors in an organisation forms a high sense of responsibility in the decision-making process (Pucheta-Martínez, Bel-Oms, \& Olcina-Sempere, 2018; Campbell \& Minguez-Vera, 2008). Kukah et al. (2016) showed the negative relationship between gender diversity, board diversity and FRQ. Furthermore, Mbir et al. (2020) and Gavious, Segev, and Yosef (2012) suggested that women on the board negatively affect earnings management, implying a significant positive relationship between board diversity and FRQ. Hence, the study presented the following:

$\mathrm{H}_{2} \quad$ There is a significant relationship between board diversity and FRQ in the Iraqi banking sector.

\subsubsection{Board Independence and FRQ}

Numerous studies have identified board independence as one of the corporate governance constructs that improve the FRQ. According to Chen et al. (2015), higher board independence monitors the manipulation in financial statements because relative to the works of dependent board members, the executive board member's work does not experience familiarity threat. Additionally, the more independent members on boards, the lower the propensity of earnings management and the higher the organisation's FRQ level. Meanwhile, Cornett, Cornett, and Marcus (2008) indicated that BOD independence provides greater experience to the company regarding their monitoring activities. Similarly, Osma and Noguer (2007) revealed that board members independent of management are crucial to an organisation's governance, mainly for discretionary accounting accruals prevention. Moreover, Peasnell, Pope, and Young (2005) highlighted the effectiveness of monitoring the board's responsibility on the number of independent directors, proposing a higher representation of independent directors due to independence and effectiveness in monitoring duties and responsibility. Therefore, the following hypothesised:

$\mathrm{H}_{3} \quad$ There is a significant relationship between Board Independence and FRQ in the Iraqi banking sector.

2.2.5 Audit Committee and FRQ

The audit committee is the standing committee comprising non-executive and independent BOD. Rezaee (2004) mentioned that the audit committee's role and responsibility are to monitor the integrity, reliability and quality of the financial reporting process without interfering in the managerial functions and the decisions on the financial statement preparation. Notably, audit committee report significantly impact the FRQ. Atu, Omimi-Ejoor, Atu, and Abusomwan (2013) also revealed that the audit committee's qualification adds to the FRQ. Most listed companies in Iraq have professional members on the board. Hence, the study examines the audit committee's function on whether it will improve the FRQ. Therefore, the study hypothesised as follows:

$\mathrm{H}_{4} \quad$ There is a significant relationship between audit committee independence and FRQ in the Iraqi banking sector.

2.2.6 Ownership Structure and FRQ

The principal-agent relationship separates ownership from those managing the business, in which shareholders sign a contract to engage managers to perform assigned functions. Meanwhile, the shareholders and managers incentives do not align as profit from the manager effort goes to the shareholders. Fama and Jensen (1983) suggested that the differences in the managers and shareholders' interests encourage the managers to take drastic steps critical to the shareholders. Hence, the severity of the agency issues depends on whether the ownership structure is concentrated or dispersed. Based on the ownership concentration, agency issues are prevented and lower the problem from dispersed ownership structure as the shareholders can easily monitor the low performing managers.

Mashhadani and Fatlawi (2012) reported that the ownership concentration reduces earnings manipulation in Iraq companies. Hence, the study includes managerial ownership and institutional ownership. Managerial ownership is a corporate governance mechanism to minimise the agency problem and improve the FRQ. Consequently, managers work in line with the shareholders' interests. Meanwhile, managers develop agency cost by over-investing or under-investing the available cashflow (Hillawi, 2012). Hence, shareholders are at a disadvantage as the managers pay more monitoring, bonding and residual cost for the organisation. Nevertheless, 
the incentive of the managers and shareholders can align through managerial ownership as the higher the stake of the manager, the higher the profit the manager shares with other shareholders. Besides, institutional ownership is an ownership structure that improves the quality of financial reporting in Iraq. Ferreira and Matos (2008) stated that firms with a larger percentage of institutional shareholders discharge their duties and responsibilities better with value and lower capital expenditure and improve the FRQ of the firms. Therefore, the study presents the following:

$\mathrm{H}_{5} \quad$ There is a significant relationship between managerial ownership and FRQ in the Iraqi banking sector.

$H_{6} \quad$ There is a significant relationship between institutional ownership and FRQ in the Iraqi banking sector.

2.2.7 Political Influence and FRQ

Numerous agency issues occur when there is government influence in the firm or with politicians as board members. Roe (2003) suggested that the pressures from politicians can induce managers to steer from profit maximising goals, affecting the company's accounting system. Meanwhile, politicians may influence managers to report selective information and present the annual reports in their best interest (Ghazalia \& Shafie, 2019; Jamil, 2020). Kalabeke, Sadiq, and Keong (2019) revealed that agency problems might create substandard financial reports or drastically reduce accounting information that is disclosed, reducing the quality of financial reporting. Several studies have also indicated that political influence negatively impacts the FRQ (Jamil, 2020; Ghazalia \& Shafie, 2019; Kalabeke et al., 2019; Sadiq, Mohamad, \& Kwong, 2019). Belkaoui (2004) reported that political influence has a low impact on the firms' earnings quality. Bushman and Piotroski (2006) also proved low financial disclosure in the firms with political influence. Thus, the following is proposed:

$\mathrm{H}_{7} \quad$ There is a significant negative relationship between Political Influence and FRQ in the Iraqi banking sector.

\subsection{Theoretical Review}

The study adopted two essential theories (agency theory and political theory) showing the relationship between corporate governance mechanisms and FRQ, specifically in Iraq's emerging economy with no proper regulation on the corporate governance codes. The agency theory is the principal-agent problem by Mitnick (1970), which occurs when the agent makes decisions on behalf of the principal. Past studies on corporate governance mechanisms provide two factors of agency theory (Daily, Dalton \& Cannella, 2019). Firstly, the companies are minimised to two participants: managers and shareholders whose interests are considered consistent and clear. Secondly, humans are disinclined and have the self-interest to sacrifice their interests for the interests of others. Hence, accounting effectively minimises the agency cost via written contracts tied to the accounting system as a vital element of corporate governance structures (Idowu \& Adegbie, 2020). Therefore, if the manager is compensated for their performance such as accounting profits, they could increase profits to increase bonus or remuneration by selecting an accounting method that might increase the profits.

The political theory involves developing voting support from shareholders instead of purchasing voting power based on George Holland Sabine. Thus, political influence in corporate governance can direct corporate governance within the firm. Consequently, the public interest is far reserved as the politicians participate in the decision making of the organisation, considering the cultural challenges (Inam, 2019). The theory also describes allocating corporate power, privileges and profits, determined through the favour of politician board members, which may eventually negatively affect the organisation's FRQ. Therefore, the theory may influence the governance developments as Iraq does not have an adequate and viable corporate code of ethics guiding the organisations.

\section{Research Data and Methods}

The study examines the relationship between corporate governance mechanisms, political influence and FRQ of listed banks under the Iraqi Stock Exchange for five years $(2015$ - 2019). The study also explains the model specification, the data, variable measurement and the estimation procedures of data analysis as stated below:

\subsection{Model Specification}

The study employed a baseline model for the relationship between corporate governance structure and FRQ and the relationship between political influence and FRQ. Based on Mbir et al. (2020) and Armstrong, Barth, Jagolinzer, and Riedl (2010), the study predicted a significant positive relationship between corporate governance and FRQ and between political influence and FRQ. Next, the following regression model was used to evaluate the influence of corporate governance structure and political influence on the FRQ of the banking sector listed under the Iraq Stock Exchange. The regression model stated as follows:

$\mathrm{FRQ}_{\text {it }}=\alpha_{0}+\alpha_{1} \mathrm{BS}_{\mathrm{it}}+\alpha_{2} \mathrm{BI}_{\mathrm{it}}+\alpha_{3} \mathrm{BD}_{\mathrm{it}}+\alpha_{4} \mathrm{AI}_{\mathrm{it}}+\alpha_{5} \mathrm{MO}_{\mathrm{it}}+\alpha_{6} \mathrm{NO}_{\mathrm{it}}+\alpha_{7} \mathrm{PC}_{\mathrm{it}}+\alpha_{8} \mathrm{LEV}_{\mathrm{it}}+\alpha_{9} \mathrm{FS}_{\mathrm{it}}+\varepsilon_{\mathrm{it}}$ Whereby, $\mathrm{BS}=$ board size; $\mathrm{BI}=$ board independence; $\mathrm{BD}=$ board gender diversity; $\mathrm{AI}=$ audit committee independence; $\mathrm{OM}=$ Managerial ownership; $\mathrm{NO}=$ institution ownership; $\mathrm{PC}=$ Political influence; LEV= leverage; and FS= firm size. Furthermore, the study included control variables that may influence the FRQ (firm 
size and leverages).

\subsection{Measurement of the Variables}

Dependent Variable: the study measured FRQ through two models from past studies. Firstly, the measurement of FRQ by McNicholas' (2002) model considered the standard deviation of the residuals as a measure of reporting quality. The bigger values of the model residual mean a considerable level of discretionary accrual and a poor quality financial report. The model is stated as follows:

$$
\begin{aligned}
& \mathrm{ACCR}_{\text {it }}=\alpha_{0}+\alpha_{1} \mathrm{CF}_{\text {it }-1}+\alpha_{2} \mathrm{CF}_{\text {it }}+\alpha_{3} \mathrm{CF}_{\text {it }+1} \alpha_{4} \Delta \mathrm{REV} \mathrm{V}_{\text {it }}+\alpha_{5} \mathrm{PPE}_{\text {it }}+\varepsilon_{\text {it }} \\
& \overline{\mathbf{T A}_{\text {it }}-1} \overline{\mathbf{T A}_{\text {it }}-1} \overline{\mathbf{T}} \mathbf{A}_{\mathrm{it}-1} \mathbf{T A}_{\mathrm{it}-1} \mathbf{T} \mathbf{A}_{\mathrm{it}-1} \mathbf{T A}_{\mathrm{it}-1}
\end{aligned}
$$

Whereby: $\mathrm{ACCR}_{\mathrm{it}-1}$ as total current accruals; $\mathrm{CF}_{\mathrm{it}}$ as operating cash flows of the current period; $\mathrm{CF}_{\mathrm{it}-1}$ as operating cash flows of the previous period; $\mathrm{CF}_{\mathrm{it}+1}$; operating cash flows of the next period; $\mathrm{REV}_{\mathrm{it}}$ as the change in revenues and $\mathrm{PPE}_{\mathrm{it}}$ as the level of property, plant and equipment. The constructs are scaled by lag total assets $\left(\mathrm{Ta}_{\mathrm{it}-1}\right)$

Secondly, the model captures the information content of earnings by Collins and Kothari (1989) and Ball and Brown (1968). Meanwhile, the stock return incorporates all the constructs information if the accounting incomes are informative, showing a good FRQ, as Ashbaugh, Collins, and LaFond (2006) indicated. Therefore, the high standard error of the residuals indicates poor quality of information. The model is stated as follows:

RET $_{\text {it }}=\alpha_{0}+\alpha_{1}$ EARN $_{\text {it }}+\alpha_{2} \Delta$ EARN $_{\text {it }}+\alpha_{3}$ NEG $_{\text {it }}+\alpha_{4}$ EARN $_{\text {it }} * \mathrm{NEG}_{\text {it }}+\varepsilon_{\text {it }}$

Whereby: $\mathrm{RET}_{\mathrm{it}}$ as annual stock returns of the current period; $\mathrm{EARN}_{\mathrm{it}}$ as net income/share of the current period; $\triangle E A R N_{i t}$ as the variation of earnings /share between ' $t-1$ ' and ' $t$ '; $N E G_{i t}$ as binary construct equal to 1 provided that the firm makes a loss, otherwise 0 ; and $E A R N_{i t} * \mathrm{NEG}_{\mathrm{it}}$ as the interaction between earnings/share and their signs. The study employed principal component analysis to examine the FRQ of the study sample better.

Independent variables: the study employed Gallery, Hutchinson, Percy, and Erkurtoglu (2008) and Mbir et al.'s (2020) measurement to estimate the board size as the square number of board members (as the relationship of board size and FRQ is non-linear); board independence as a non-executive director to total directors; board gender diversity by the number of women on the board to the total board member; and audit committee independence as a non-executive member of the audit committee to the total number of the audit committee member, in line with Kukah et al. (2016). Based on Nelson and Devi (2013), the audit committee independence is measured by the number of independent non-executive directors on the audit committee to the total audit committee members. The measurement of both the dependent variables and independent variables are summarised in the Table 1:

Table 1. Variables Measurement (Descriptions and Source)

\begin{tabular}{|l|l|l|}
\hline Variables & Measurement & Source \\
\hline FRQ & $\begin{array}{l}\text { Discretionary accrual deducted from total accrual of } \\
\text { the company }\end{array}$ & $\begin{array}{l}\text { Annual report of listed } \\
\text { firms 2015-2019 }\end{array}$ \\
\hline Board Size & Total number of board member & $\begin{array}{l}\text { Annual report of listed } \\
\text { firms 2015-2019 }\end{array}$ \\
\hline Board Independence & $\begin{array}{l}\text { The number of non-executive directors to total number } \\
\text { of board size }\end{array}$ & $\begin{array}{l}\text { Annual report of listed } \\
\text { firms 2015 - 2019 }\end{array}$ \\
\hline Board Gender Diversity & $\begin{array}{l}\text { The proportion of women directors to the total number } \\
\text { of board }\end{array}$ & $\begin{array}{l}\text { Annual report of listed } \\
\text { firms 2015 - 2019 }\end{array}$ \\
\hline $\begin{array}{l}\text { Audit Committee } \\
\text { Independence }\end{array}$ & $\begin{array}{l}\text { The proportion of outside directors to the total number } \\
\text { of audit committee members }\end{array}$ & $\begin{array}{l}\text { Annual report of listed } \\
\text { firms 2015 - 2019 }\end{array}$ \\
\hline Managerial Ownership & $\begin{array}{l}\text { The square root of the percentage of the managerial } \\
\text { ownership }\end{array}$ & $\begin{array}{l}\text { Annual report of listed } \\
\text { firms 2015-2019 }\end{array}$ \\
\hline Institution Ownership & $\begin{array}{l}\text { The square root of the percentage of the institutional } \\
\text { ownership }\end{array}$ & $\begin{array}{l}\text { Annual report of listed } \\
\text { firms 2015 - 2019 }\end{array}$ \\
\hline Political Influence & $\begin{array}{l}\text { If there is a politician, it is one (1), otherwise, it is zero } \\
\text { (0) }\end{array}$ & $\begin{array}{l}\text { Annual report of listed } \\
\text { firms 2015 - 2019 }\end{array}$ \\
\hline Leverage & $\begin{array}{l}\text { Long-term debt to total assets of the firm } \\
\text { firms 2015 - 2019 }\end{array}$ \\
\hline Firm size & Log of total assets & $\begin{array}{l}\text { Annual report of listed } \\
\text { firms 2015 - 2019 }\end{array}$ \\
\hline
\end{tabular}

The companies in Iraq are classified according to the Iraq Stock Exchange (ISX) for 2016 into nine categories based on the area of activities. These include banking sectors (34), insurance services (5), investment (9), tourism and hotel (10), money transfer (10), transportation, agriculture and industry (7). The study considered only the banking sector; Hence, the study population comprised the 34 banks listed under the ISX between 2015 to 2019. The banking service was considered due to the different regulations guiding the banks in 
Iraq than other sectors. Furthermore, the study processed data using Stata version 15.0, using the random effect estimator based on Hausman tests. For the study to assess the model adequacy, multi-collinearity and joint significance were tested. Finally, the study analysed the impact of corporate governance and political influence on FRQ through regression analysis.

\section{Analysis and Interpretation of Findings}

\subsection{Descriptive Statistics}

The study considered mean and standard deviation as the descriptive statistics as this refer to the measure of central tendency and measure of dispersion. The mean refers to the average value of the dataset, whereas standard deviation refers to a measure that presents an index of variability in the dataset and is also known as the square root of variance. The results are shown in Table 2, the average value of the dependent variables FRQ is five years period, the mean value of the FRQ was indicated to be $8.5 \%$, whereas the minimum and maximum values were $0.000(0 \%)$ and $0.553(55.3 \%)$.

The results also suggested that institutional ownership was the highest among the Iraqi firms: ranging from zero (0) to $88 \%$, with a mean of $52.5 \%$, higher than Shayan and Özcebe (2017) with a mean of $32 \%$. Additionally, the board size variable has a minimum of four members on the BOD and a maximum of 17 members. The average size of the boards is 7 , and the standard deviation of 2 . For board gender diversity, women participation in the BOD has an average of $6.3 \%$, with a minimum of $0 \%$ and maximum of $6 \%$. The political connection and ownership structures were measured based on continuous variables. Table 3 shows the results of the descriptive statistics.

Table 2. Descriptive Statistics

\begin{tabular}{lcccc}
\hline Constructs & Mean & SD & Min & Max \\
\hline FRQ & 0.085 & 0.065 & 0.000 & 0.553 \\
Board Size (BS) & 7.015 & 2.112 & 4.000 & 17.000 \\
Board Independence (BI) & 0.215 & 0.175 & 0.000 & 0.130 \\
Board Gender Diversity (BD) & 0.063 & 0.122 & 0.000 & 0.060 \\
Audit Committee Independence (AI) & 0.240 & 0.150 & 0.010 & 0.810 \\
Managerial Ownership (MO) & 0.110 & 0.151 & 0.000 & 0.926 \\
Institution Ownership (NO) & 0.525 & 0.231 & 0.000 & 0.883 \\
Political Influence (PC) & 0.558 & 0.523 & 0.000 & 4.000 \\
Leverage (LEV) & 0.733 & 0.214 & 0.005 & 1.000 \\
Firm Size (FS) & 14.871 & 1.889 & 10.213 & 20.221 \\
\hline
\end{tabular}

\subsection{Correlation Analysis}

The correlation analysis was used to test multi-collinearity relationships between the constructs in the regression model. Mustapha, Rashid, Ado, and Ademola (2019) and Gujrati (2004) reported that the correlation could be proven if the r-value is 0.8 and above. Pallant (2011) stated that the correlation of 0 shows no relationship, 1.0 indicates a positive relationship, whereas -1 is a perfect negative correlation. Besides, Cohen (1988) suggested the guidelines $(r=0.1-0.29$ as small; $r=0.30-0.49$ as medium; and $r=0.5-1.0$ as large relationship). Table 4 indicates that the constructs are significantly correlated as no constructs were above 0.9 . Hence, the results showed no multi-collinearity problems as per Hair, Hult, Ringle, and Sarstedt (2021).

Table 3. Correlation Analysis

\begin{tabular}{|c|c|c|c|c|c|c|c|c|c|c|}
\hline Constructs & FRQ & BS & BI & BD & AI & MO & NO & PC & LEV & FS \\
\hline FRQ & 1.000 & & & & & & & & & \\
\hline $\mathrm{BS}$ & $.201^{* *}$ & 1.000 & & & & & & & & \\
\hline BI & $.202^{* *}$ & $.112^{*}$ & 1.000 & & & & & & & \\
\hline $\mathrm{BD}$ & .040 & $.212^{*}$ & .030 & 1.000 & & & & & & \\
\hline AI & .079 & .072 & $.101^{*}$ & -.039 & 1.000 & & & & & \\
\hline $\mathrm{MO}$ & $.081^{*}$ & $.211^{* *}$ & .092 & $.123^{* *}$ & .045 & 1.000 & & & & \\
\hline NO & $.044^{* *}$ & $.212^{*}$ & .083 & $.110^{*}$ & $.141^{*}$ & $.101^{*}$ & 1.000 & & & \\
\hline $\mathrm{PC}$ & $-.101^{*}$ & .026 & $.132^{* *}$ & $.338^{* *}$ & -.088 & .095 & $-.160^{*}$ & 1.000 & & \\
\hline LEV & $.111^{*}$ & $.340^{* *}$ & $.254^{*}$ & .057 & .115 & $.213^{* *}$ & $.230^{* *}$ & $.170^{*}$ & 1.000 & \\
\hline FS & $.648^{* *}$ & $.200^{* *}$ & $.261^{*}$ & -.047 & $.181^{*}$ & $.291^{* *}$ & $.361^{* *}$ & $.226^{* *}$ & $-.136^{*}$ & 1.000 \\
\hline
\end{tabular}

FRQ (FRQ); Board Size (BS); Board Independence (BI); Board Gender Diversity (BD); Audit Committee Independence (AI); Managerial Ownership (MO); Institution Ownership (NO); Political Influence (PC); Leverage (LEV); Firm Size (FS) 


\subsection{Regression Result and Testing of Hypotheses}

The model was tested using fixed-effect regression after running the Hausman test to select the appropriate method between a fixed effect and a random effect. Nevertheless, the $\mathrm{R}^{2}$ value is $0.422(42 \%)$, suggesting the overall influence of corporate governance and political influence on FRQ in the model. Table 4 shows the results of the multiple regression analysis and hypotheses testing.

Table 4. Multiple Regression Analysis Results

\begin{tabular}{lcccc}
\hline FRQ & Coef. & SE & t-value & p-value \\
\hline Board Size (BS) & .21211 & .10400 & $2.039^{* *}$ & .0120 \\
Board Independence (BI) & .08640 & .05964 & 1.450 & .1531 \\
Board Gender Diversity (BD) & .00055 & .00130 & .4230 & .6920 \\
Audit Committee Independence (AI) & .24021 & .15032 & 1.598 & .1006 \\
Managerial Ownership (MO) & .10240 & .05101 & $2.007^{* *}$ & .0450 \\
Institution Ownership (NO) & .12520 & .23125 & .5414 & .1442 \\
Political Influence (PC) & -.53030 & .22315 & $-2.3764^{* *}$ & .0321 \\
Leverage (LEV) & .14612 & .01023 & $10.174^{* * *}$ & .0002 \\
Firm Size (FS) & .00421 & .00312 & .86312 & .3881 \\
Constants & -1.5812 & .19453 & $-8.134^{* * *}$ & .0000 \\
\hline R- Square & .4220 & & & \\
Prob. (F-statistic) & .0008 & & & \\
Hettest (Chi2) & .4101 & & & \\
Hausman Test (Chi2) & .3302 & & & \\
Observation(N) & 170 & & & \\
\hline
\end{tabular}

Note: ***p $<0.01 @ 1 \%$;**p $<0.05 @ 5 \%$; \&*p $<0.01 @ 10 \%$

The results of the multiple regression for the board size showed a positive and significant relationship with FRQ as a $5 \%$ level of significance with a beta value of $21 \%$. Hence, the significant positive value verified an increase in the board members increases the quality of financial reporting in line with the agency theory that proposed the increase in the board size anchors improves the FRQ (Al-Shaer, Salama, \& Toms, 2017; Mishra \& Malhotra, 2016; Ismail \& Kamarudin, 2017). For board gender diversity, the study showed an insignificant relationship with the FRQ. Besides, board independence has an insignificant relationship with FRQ. Thus, the study revealed the negative contribution of the women on the BOD on the FRQ. The results confirmed that any number of women on the board would minimise the FRQ of the listed banks in the Iraq stock exchange. Therefore, the results contradicted with the study hypothesis and agency theory assumption (Mustapha et al., 2019; Abdulmalik \& Ahmad, 2016).

Based on the audit committee independence, the study indicated a positive and insignificant relationship with FRQ. Hence, an increase of one member of non-executive independence will decrease reporting quality to mandate more external monitoring. Therefore, the study hypothesis is rejected and contradict with the proposed agency theory (Aanu, Odianonsen, \& Taiwo, 2015). Based on the relationship between ownership structure and FRQ, managerial ownership showed a positive and significant relationship with the FRQ of listed banks in the Iraq stock exchange. Therefore, the significant positive value of the manager in ownership justified an increase in the monitoring and the FRQ, consistent with the agency theory verifying the increase on the managerial ownership anchor improvement on the FRQ.

Meanwhile, the institutional ownership indicated an insignificant relationship with FRQ. Thus, the involvement of institutions in business ownership could reduce the FRQ. The study confirms (Mustapha et al., 2019) who found an insignificant relationship with FRQ. For board members' political influence, the results proved a significant negative relationship of board members with the political influence on FRQ. Therefore, the negative result of the political influence of some board members could negatively influence the organisation's decision-making. The findings support the proposed theory of political influence model, whereby the political influence of board members has a negative influence on the performance of the FRQ of the listed banks in the Iraqi stock exchange.

\section{Conclusions and Recommendations}

The study examined the impact of board effectiveness, ownership structure and political influence on FRQ of the Iraqi banking sector. Iraq is an emerging economy whereby corporate governance practices have been introduced to establish and maintain companies' good quality corporate culture. Panel data was employed in the study and the Hausman test was used to select between fixed effect and random effect, whereby the fixed effect was selected because the null hypothesis is rejected. Thus, the board size has a positive and significant relationship with FRQ in the sample firms analysis. Nonetheless, board independence and audit independence have an insignificant impact on FRQ. The Iraqi corporate governance manual does not define the role of the independent 
non-executive directors explicitly. Besides, the study sample organisation have a high ratio of independent nonexecutive to minimise the board independence. Equally, institutional ownership has no relationship with FRQ. The institution is interested in the reporting quality and they look after the company decisions. Nonetheless, institutional ownership has no influence on FRQ in both techniques employed to estimate the model. Interestingly, managerial ownership has a positive relationship with FRQ in accounting and market measures. Therefore, managerial and shareholder interests align when management ownership increases. Furthermore, the political influence of some members of the board has a negative impact on the FRQ.

The results showed that the financial reporting system improves the quality of financial information and provides an enabling environment to the shareholders by adding value to their confidence to create more accurate decisions. The study recommends relevant banks in Iraq and worldwide to increase the good governance practices by boards, audit committees, ownership structure and political connection towards the FRQ and improve organisational performance. The study further suggested that future studies should be performed in other sectors as a comparison and generalise the study. Finally, new studies should be conducted to expand the time frame of the period of the study.

\section{References}

Aanu, O., Odianonsen, I., \& Taiwo, A. (2015). Audit committee financial expertise: Antidote for FRQ in Nigeria? Mediterranean Journal of Social Sciences, 6(1), 136-146. https://doi.org/10.5901/mjss.2015.v6n1p136

Abdulmalik, O., \& Ahmad, A. C. (2016). Audit fees, corporate governance mechanisms, and FRQ in Nigeria. DLSU Business \& Economics Review, 26(1).

Agrawal, A., \& Chadha, S. (2005). Corporate governance and accounting scandals. Journal of Law and Economics, 48(2), 371-406.

Almanasir, A. H. A., \& Shivaraj, B. (2017). Voluntary corporate governance disclosure innovative evidence: the case of Jordan. Journal of Reviews on Global Economics, 6, 443-454.

Al-Obeidi, K., \& Asim, N. (2011). The role of corporate governance in addressing the structural imbalances in the Iraqi stock market. Journal of Accounting \& Financial Studies, 137-170.

Al-Shaer, H., Salama, A., \& Toms, S. (2017). Audit committees and FRQ: Evidence from UK environmental accounting disclosures. Journal of Business Ethics, 18(1), 2-21. https://doi.org/10.1007/s10551-015-2679-0

Antonio, M. S., Laela, S. F., \& Darmawan, R. R. (2019). Corporate governance, earnings quality and market response: Comparison of islamic and non-islamic stock in the Indonesian capital market. Academy of Accounting and Financial Studies Journal, 23, 1-22.

Arieftiara, D., \& Utama, S. (2018). Do FRQ and corporate governance have simultaneous effect? Evidence from Indonesian manufacturing companies. AKRUAL: Jurnal Akuntansi, 9(2), 168-185.

Armstrong, C. S., Barth, M. E., Jagolinzer, A. D., \& Riedl, E. J. (2010). Market reaction to the adoption of IFRS in Europe. The Accounting Review, 85(1). 31-61. https:// doi.org/10.2308/accr.2010.85.1.31

Ashbaugh, H., Collins, D., \& LaFond, R. (2006). The effects of corporate governance on firms' credit ratings. Journal of Accounting and Economics, 42, 203-243.

Atu, O. G., Omimi-Ejoor, O. K., Atu, O. V., \& Abusomwan, R. E. (2013). The role of audit committee in enhancing financial reporting in Nigeria. Journal of Business and Management, 13(1), 27-34.

Ball, R. \& Brown, P. (1968). An empirical evaluation of accounting income numbers. Journal of Accounting Research, 6(2), 159-178.

Beasley, M. S., Blay, A. D., Lewellen, C., \& McAllister, M. (2018). The association between board risk oversight and the risk of material misstatement.

Beest, F. V., Braam, G. J. M., \& Boelens, S. (2009). Quality of financial reporting: Measuring qualitative characteristics.

Belkaoui, A. R. (2004). Politically-connected firms: Are they connected to earnings opacity. Research in Accounting Regulations, 17. Retrieved from http://papers.ssrn.com/sol3/papers.cfm?abstract_id=459300

Bushman, R. M., \& Piotroski, J. D. (2006). Financial reporting incentives for conservative accounting: The influence of legal and political institutions. Journal of Accounting and Economics, 42(1-2), 107-148.

Campbell, K., \& Mínguez-Vera, A. (2008). Gender diversity in the boardroom and firm financial performance. Journal of Business Ethics, 83(3), 435-451.

Chen, X., Cheng, Q., \& Wang, X. (2015). Does increased board independence reduce earnings management? Evidence from recent regulatory reforms. Review of Accounting Studies, 20(2), 899-933.

Cohen, J. (1988). Statistical power analysis for the behavioral sciences (2nd ed.). Hillsdale, NJ: Erlbaum.

Collins, D., \& Kothari, S. (1989). An analysis of intertemporal and cross-sectional determinants of earnings response coefficients. Journal of Accounting and Economics, 11, 143-181.

Cornett, M. M., Cornett, A. J., \& Marcus, H. (2008). Tehranian corporate governance and pay-for-payments: The impact of earnings management. Journal of Financial Economics, 87(2008), 357-373.

Daily, C. M., Dalton, D. R., \& Cannella, A. A. (2019). Corporate governance: Decades of dialogue and data. 
Academy of Management Review, 28(3), 371-382.

Doski, D. (2015). The necessity of issuing a corporate governance code for the Kurdistan Region. Journal of Finance and Accountancy, 18.

Ene, E. E., \& Bello, A. I. E. (2016). The effect of corporate governance on bank's financial performance in Nigeria. IOSR Journal of Business and Management, 18(11), 99-107.

Fakhfakh, A. J. (2016). Audit reports timeliness: Empirical evidence from Jordan. Procedia - Social and Behavioral Sciences, 2-13. https://doi.org/10.1016/j.sbspro.2012.09.229

Fama, E. F., \& Jensen, M. (1983). Seperation of ownership and control. Journal of Law and Economics, 6(26), 327-349.

Fekadu, G. W. (2015). Corporate governance on financial performance of insurance industry. Corporate Ownership \& Control, 13(1), 841-849.

Ferreira, M. A., \& Matos, P. (2008). The colors of investors' money: The role of institutional investors around the world. Journal of Financial Economics, 88(3), 499-533.

Gallery, N., Hutchinson, M. R., Percy, M., \& Erkurtoglu, L. (2008). An investigation of the association between corporate governance, earnings management and the effect of governance reforms. Accounting Research Journal, 21(3). https://doi.org/10.1108/ 10309610810922495

Gavious, I., Segev, E., \& Yosef, R. (2012). Female directors and earnings management in high - technology firms. Pacific Accounting Review.

Ghazalia, A. W., \& Shafie, N. A. (2019). The relationship between audit committee, political influence and FRQ: Malaysian evidence. Management \& Accounting Review (MAR), 18(2), 193-244.

Gujarati, D. (2004). Basic econometrics, fourth edition. The McGraw-Hill Companies, New York 2004.

Hair Jr, J. F., Hult, G. T. M., Ringle, C. M., \& Sarstedt, M. (2021). A primer on partial least squares structural equation modeling (PLS-SEM). Sage Publications.

Han, S. (2005). Ownership structure and quality of financial reporting. Working Paper of University of Illinois.

Hermanto, S. B. (2019). The role of mediating the publication on the influence of corporate governance on performance. In Proceedings of the 1st International Conference on Business, Law and Pedagogy at Sidoarjo, Indonesia.

Hillawi, A. H. (2012). Corporate governance and its impact on improving the performance of business organizations: An empirical study on a sample of industrial companies (mixed and private) are listed on the Iraq Stock Exchange for the period from 1999 to 2008. [Master dissertation, University of Karbala].

Hillman, A. J., \& Dalziel, T. (2003). Boards of directors and firm performance: Integrating agency and resource dependence perspectives. Academy of Management Review, 28(3), 383-396.

Huynh, Q. L. (2020). A triple of corporate governance, social responsibility and earnings management. The Journal of Asian Finance, Economics, and Business, 7(3), 29-40.

Idowu, I. A. \& Adegbie F. F. (2020). Corporate governance and FRQ in Nigeria deposit money banks. International Journal of Scientific and Research Publications (IJSRP), 10(8). http://doi.org/10.29322/IJSRP.10.08.2020.p10471

Inam, W. (2019). Corporate governance - New corporate mantra? Retrieved from http://www.templers-law.com

International Accounting Standards Board (IASB) (2017). Analysis of the IFRS profiles for the IFRS for SMEs Standard. Retrieved from http://www.ifrs.org/Use-around-the-world/Pages/Analysis-of-SMEprofiles.aspx

Ismail, W. A. W., \& Kamarudin, K. A. (2017). Deceptive versus informative income smoothing: Evidence from audit committee attributes. In Proceedings of ICOPS2017 (pp. 781-789).

Jamil, N. N. (2020). The power of political connections: Review on the impacts of audit committee and corporate governance. Journal of Public Administration and Governance, 10(1).

Kalabeke, W., Sadiq, M., \& Keong, O. C. (2019). Auditors tenure and FRQ: Evidence from a developing country. International Journal of Asian Social Science, 9(5), 335-341.

Khudair, R. M. (2012). The influence of corporate governance on stock's market value in bank's companies. Journal of Baghdad College for Economic Sciences, 22, 299-316.

Klai, N., \& Omri, A. (2011). Corporate governance and FRQ: The case of Tunisian firms. International Business Research, 4(1), 158-166.

Kukah, M. A., Amidu, M., \& Abor, J. Y. (2016). Corporate governance mechanisms and accounting information quality of listed firms in Ghana. African Journal of Accounting, Auditing and Finance, 5(1), 38-58. https://doi.org/10.1504/AJAAF.2016.077599

Mahrani, M., \& Soewarno, N. (2018). The effect of good corporate governance mechanism and corporate social responsibility on financial performance with earnings management as mediating variable. Asian Journal of Accounting Research.

Mashhadani, B. N. A., \& Fatlawi, L. N. M. (2012). Approaches adopted in measuring the impact corporate earnings management governance mechanisms in reduced. Journal of Administration and Economics, $35(93), 26-56$. 
Masud, M., Kaium, A., Bae, S. M., Manzanares, J., \& Kim, J. D. (2019). Board directors' expertise and corporate corruption disclosure: The moderating role of political connections. Sustainability, 11(16), 4491.

Mbir, D. E. G., Agyemang, O. S., \& Tackie, G. (2020). IFRS compliance, corporate governance and FRQ of GSE-listed non-financial firms. Cogent Business \& Management, 7(1).

McNicholas, M. (2002). Discussion on the quality of accruals and earnings: The role of accrual estimation errors. The Accounting Review, 77(1), 61-69.

Mishra, M., \& Malhotra, A. K. (2016). Audit committee characteristics and earnings management: Evidence from India. International Journal of Accounting and Financial Reporting, 6(2), 247-273. https://doi.org/10.5296/ijafr.v6i2.10008

Mitnick, B. M. (1973). Fiduciary rationality and public policy: The theory of agency and some consequences. In Proceedings of 1973 Annual Meeting of the American Political Science Association, New Orleans, LA.

Mohammadi, M. A. D. (2017). Corporate governance and financial information disclosure in a developing country [Doctoral dissertation, Universiti Teknologi Malaysia].

Mohammed, N. F., Sanusi, Z. M., Noordin, B. A. A., \& Harjito, A. (2016). Political influence on FRQ of public listed firms in Malaysia. International Journal of Economics and Management, 10, 303-318.

Mustapha U. A., Rashid N., Ado A. B., \& Ademola L. S. (2019). The effect of corporate governance attributes on audit quality in Nigeria. International Journal of Recent Technology and Engineering (IJRTE), 8(4).

Najim, B. (2013). Integrative role of internal audit in the effectiveness of institutional control, a prospective study in a sample of Iraqi banks and companies. GCC Economic Journal.

Nelson, S. P., \& Devi, S. (2013). Audit committee experts and earnings quality. Corporate Governance: The International Journal of Business in Society.

Osma, B. G., \& Noguer, B. G. D. A. (2007). The effect of the board composition and its monitoring committees on earnings management: Evidence from Spain. Corporate Governance: An International Review, 15(6), $1413-1428$.

Pallant, J. (2011). SPSS survival manual. A step by stem guide to data analysis using SPSS for windows (version 25). NSW: Allen \& Unwin.

Paul, G. D., Ebelechukwu, E. C., \& Yakubu, S. (2015). Impact of corporate governance on financial performance of microfinance banks in north central Nigeria. International Journal of Humanities Social Sciences and Education, 2(1), 153-170.

Peasnell, K. V., Pope, P. F., \& Young, S. (2005). Board monitoring and earnings management: Do outside directors influence abnormal accruals? Journal of Business Finance \& Accounting, 32(7\&8), 1311-1346.

Pucheta-Martínez, M. C., Bel-Oms, I., \& Olcina-Sempere, G. (2018). The association between board gender diversity and financial reporting quality, corporate performance and corporate social responsibility disclosure: A literature review. Academia Revista Latinoamericana de Administración.

Rezaee, Z. (2004). Corporate governance post sarbanes-oxley: Regulations, requirements, and integrated processes. New Jersey: John Wiley \& Sons.

Rich, K. T. (2009). Audit committee accounting expertise and changes in FRQ [Doctoral dissertation, University of Oregon].

Roe, M. (2003). The legacies of Mahathir's privatisation policy. Retrieved from http://www. Aseanfocus.com/asiananalysis/article.cfm?articleID=721

Sadiq, M., Mohamad, S., \& Kwong, W. C. G. (2019). Do CEO incentives mediate the relationship between political influences and FRQ? International Journal of Asian Social Science, 9(3), 276-284.

Sánchez - Ballesta, J. P., \& García - Meca, E. (2007). A meta - analytic vision of the effect of ownership structure on firm performance. Corporate Governance: An International Review, 15(5), 879-892.

Shayan, N. A., \& Özcebe, L. H. (2017). Anne ölümleri: Afganistan ve komşu ülkelerin karşılaştırılması. Turk $J$ Public Health, 15(3).

Terjesen, S., Couto, E. B., \& Francisco, P. M. (2016). Does the presence of independent and female directors impact firm performance? A multi-country study of board diversity. Journal of Management \& Governance, 20(3), 447-483.

Trai, D. N., Kha, T. M., Trung, L. N. T., \& Dung, N. T. (2018). The impact of corporate governance on financial reporting quality - Empirical evidence from Vietnam. International Journal of Accounting and Financial, 112.

Vafeas, N. (2000). Board structure and the informativeness of earnings. Journal of Accounting and Public Policy, 19(2), 139-160. http://doi.org/10.1016/s0278-4254(00)00 006-5

Zulaikah, S., Larasati, D. A., \& Harymawan, I. (2019). Government ownership, human resources disclosure, and firm performance: Evidence from the banking industry in Indonesia. International Journal of Innovation, Creativity and Change, 9(8), 238-264. 